https://doi.org/10.52240/1857-2367.2020.2(21).21

\title{
CONVOLVULUS CANTABRICA L. (CONVOLVULACEAE) IN THE «LOWER PRUT» BIOSPHERE RESERVE (REPUBLIC OF MOLDOVA)
}

\author{
Polina CASSIR ${ }^{1}$, Tatiana IZVERSCAIA², Nina CIOCARLAN², Veaceslav GHENDOV \\ ${ }^{1 N}$ atural Scientific Reserve" Lower Prut", \\ Slobozia Mare (Cahul), Republic of Moldova \\ 2"Al. Ciubotaru” National Botanical Garden (Institute), \\ Chisinau, Republic of Moldova
}

\begin{abstract}
The morphometric parameters, density of individuals, reproductive strategy and the ability of adaptation of the populations of Convolvulus cantabrica L. in the "Lower Prut" Biosphere reserve (Cahul district) were studied. There were registered 7 fragmented populations (the biggest being cca $0,5 \mathrm{ha}$ ).
\end{abstract}

Key words: Convolvulus cantabrica, flora, "Lower Prut" biosphere reserve, Republic of Moldova

Currently, the processes of extinction of species and a decrease in the area of habitats of natural and semi-natural steppe vegetation are increasing. There is an urgent need to study the current state of conservation of rare and valuable plant species found in such areas. Due to the increasing sensitivity to changes in environmental conditions, accompanied by increased anthropogenic pressure, many species of steppe plants are considered endangered, many of them are taken under state protection.

In the year 2000, after the adherence of the Republic of Moldova to the Ramsar convention, the lake area of Lower Prut got the status of wetland of international importance. The Ramsar convention calls for the wise use of wetlands and adjacent territories, and the Convention on Biological Diversity promotes the ecosystem approach for sustainable management of natural resources, it follows that for the improvement of ecosystem quality in the lower Prut region. In order to restore and maintain their natural potential the main objectives of the reserves are to ensure conservation and, at the same time, to ensure sustainable use of natural resources as well as to raise awareness about the value of the Biosphere ecosystems [3]. A Biosphere reserve conserves examples of characteristic ecosystems (containes strictly protected areas, traditional use areas, e.g. for fishing etc., and a buffer zone to reduce external impacts) [3]. Among the Ramsar concerned ecosystem - wetlands, the Lower Prut reserve incorporates a habitat of PontoSarmatic steppes. A portion of the native Prut river bank (along with the adjacent ravine areas) represent slope steppic habitat with more or less closed grasslands, dominated by tussock-forming grasses. Loess hills of south-west and west expositions are quite steep, in some places up to almost vertical walls [1].

The total surface of the "Lower Prut" Biosphere reserve is 14771,04 hectares, including forest lands of 824 ha and the adjacent terrains: the majority of the agricultural fields are private properties, the pastures (mainly arid steppe open lands) are public property.

The aim of this work is to study the state of populations of rare, Critically Endangered [2] vascular plant in the Republic of Moldova - Convolvulus cantabrica L. - Cantabrian Morning Glory, within the boundaries of the "Lower Prut" Biosphere reserve, Cahul district. The research was conducted during 2015-2020. We determined peculiarities 

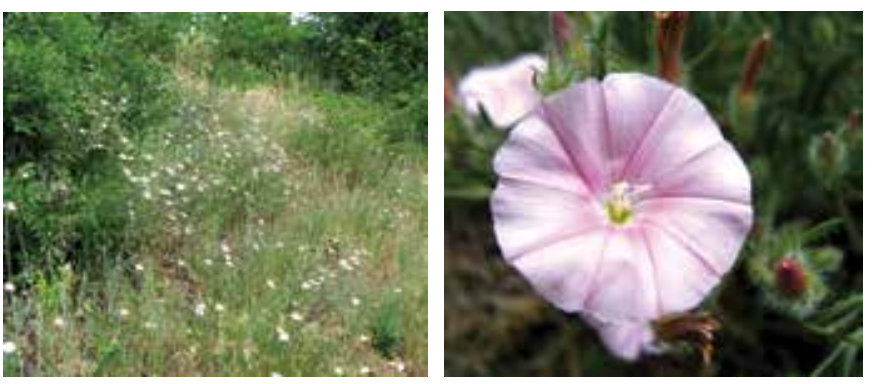

Figure 1. Convolvulus cantabrica in the steppe grassland of distribution, frequency of occurrence and population size and studied population structure of the Morning Glory (Figure 1).

The species was registered in 7 fragmented populations (in the vicinity of vill. Văleni (2 sites), Slobozia Mare (2), CâșlițaPrut (2) and Giurgiulești (1

site). The biggest and most preserved population of it has been detected in the hilly site between Văleni and Slobozia Mare (N 45 36' 27', E $28^{\circ} 10^{\prime}$ '13"). The area of this population is cca 0,5 ha, density of individuals vary from 2 to 5 mature and 3-12 juvenile individuals per square meter. Up to $60 \%$ of the seedlings do not reach maturity. The main threats to the populations are hill afforestation and steppe habitat transformation due to intense grazing practices.

Acknowledgments. The research was supported by the NARD through the Project "Research and conservation of vascular flora and macromycobiota of the Republic of Moldova", 20.80009.7007.22 (contract Nr. 71/PS/2020).

\section{BIBLIOGRAPHY}

1. Ciocarlan, N.; Ghendov, V.; Izverscaia, T.; Stefanache, C.; Carlen, C.; Simonnet, X. Medicinal Artemisia L. species (A. annua, A. absinthium and A. lerchiana) in Republic of Moldova. Chişinău: S.n., 2017 (F.E.-P. Tipografia Centrală). 144 p.

2. Gînju S., Ciocârlan N. Convolvulus cantabrica L. /The Red Book of the Republic of Moldova. $3^{\text {rd }}$ ed., Ch.: Ştiinţa, 2015, p. 59.

3. Plan comun de management pentru arii natural protejate. Programul Operațional Comun RomaniaUcraina-Republica Moldova 2007-2013. Tulcea, România, 2013. 215 p. 